\title{
Maedi-visna virus infection of ovine mammary epithelial cells
}

\author{
Rosa BOLEA ${ }^{\text {a*}}$, Eva MONLEÓN ${ }^{\mathrm{a}}$, Librado CARRASCO ${ }^{\mathrm{b}}$, \\ Antonia VARGAS ${ }^{\mathrm{a}}$, Damián DE ANDRÉS ${ }^{\mathrm{c}}$, Beatriz AMORENA ${ }^{\mathrm{c}}$, \\ Juan José BADIOLA ${ }^{\mathrm{a}}$, Lluís LUJÁN ${ }^{\mathrm{a}}$
a Department of Animal Pathology, University of Zaragoza, Veterinary Faculty, Miguel Servet 177, 50013 Zaragoza, Spain
b Department of Anatomy and Comparative Pathology, University of Córdoba, Veterinary Faculty, Campus de Rabanales, 14014 Córdoba, Spain
c Instituto de Agrobiotecnología y Recursos Naturales, Spanish Council for Scientific Research \\ (C.S.I.C.), Public University of Navarra 31192, Mutilva Baja, Spain
}

(Received 10 March 2005; accepted 29 August 2005)

\begin{abstract}
The aim of this work was to perform a complete study of maedi-visna virus (MVV) infected mammary glands of naturally-infected sheep, and to determine if cells other than macrophages undergo a productive viral infection in this organ. Fifteen seropositive and two seronegative ewes were selected from MVV-infected flocks on the basis of clinical indurative mastitis and three sheep from an MVV-free flock. Within the mammary gland, MVV-positive cells were located by immunohistochemistry in the stroma and the epithelial alveolar barrier, most likely the ovine mammary epithelial cells (OMEC) of the acini. In situ hybridization confirmed these findings. Ultrastructural studies showed the presence of lentivirus-like particles budding off the cell surface in the alveolar barrier and also free in the acinar lumen. The presence of mammary histopathological lesions and MVV together with clear indications of productive infection (demonstration of a cytopathic effect in OMEC cultures and infection of co-cultures) were observed in the 15 seropositive and one of the seronegative sheep from the infected flock. These findings demonstrate that the OMEC were infected in vivo and probably underwent productive infection when studied ex-vivo. The OMEC of MVV-free sheep, which had subsequently been infected in vitro with MVV, also showed productive infection when challenged in vitro, confirming the replication of MVV in OMEC in vitro. The presence of MVV-infected OMEC in the mammary gland from infected animals, the productive infection in these OMEC and the release of lentiviral particles to the acinar lumen may have relevance in the pathogenesis and transmission of MVV infection.
\end{abstract}

maedi-visna / mammary gland / epithelial cells / indurative mastitis / ovine

\section{INTRODUCTION}

Maedi-visna virus (MVV), a lentivirus closely related to the human immunodeficiency virus (HIV), causes a chronic wasting disease in sheep, characterized by pneu- monia, mastitis, encephalitis and/or arthritis $[7,32]$. Classically, the most important syndrome of the infection is interstitial pneumonia [7, 41] which is only seen in adult animals and shares common features with the respiratory affection observed in children

\footnotetext{
* Corresponding author: rbolea@unizar.es
} 
infected by HIV [39]. The mammary affection was described in the early nineteeneighties and seems to be as important as the pneumonic syndrome, at least in some geographical areas [22]. This type of mastitis is clinically difficult to detect and mainly consists in a diffuse hardening of the mammary gland often observed after parturition [12, $25,26]$. The main clinical sign is the lack of milk production, which is normally detected by a deficient growth of the lamb [34]. In all the target organs, lesions appear to be the consequence of viral replication in tissue macrophages [35]. Contrarily to HIV, MVV does not seem to replicate in lymphocytes in vivo and is unable to produce a patent HIV-type immunosupression in vivo [11]. It has been assumed that tissue macrophages are the only target cells for MVV, but several studies have demonstrated that MVV can infect a broader cell range such as oligodendrocytes, astrocytes, fibroblasts [10], endothelial cells [6] and smooth muscle cells [21], among others. It is known that the epithelial cells from granulosa, goat oviduct and those present in goat milk are highly permissive in vitro to the caprine arthritis and encephalitis virus (CAEV) [14, 15, 27, 28]. Even early embryonic cells from in vivo-produced goat embryos transmit this virus [16].

In the sheep mammary gland, little is known on the location and replication of MVV although tissue macrophages have been proposed to be the cells harbouring the virus and responsible for the presence of MVV in milk [8, 19, 36]. However, ovine mammary epithelial cells (OMEC) can be CAEV targets, at least in vitro [20]. In a recent work using in situ PCR in association with immunohistochemistry on tissue sections of the mammary gland from naturally infected sheep as confirmed by their ELISApositive status, Carrozza et al. [3] demonstrated the presence of the MVV genome in interstitial fibroblasts, acinar epithelial cells, macrophages, endothelial cells, adipocytes and desquamating epithelium or macrophages in the lumen of the acini.
The aim of this work was to carry out histopathological, ultrastructural and infectivity studies in order to investigate the location of MVV in the mammary gland of naturally-infected sheep, specifically in OMEC, and to determine if a productive viral infection occurs in these cells. The results obtained could have important epidemiological consequences in MVV transmission.

\section{MATERIALS AND METHODS}

\subsection{Animals, infection and mammary gland status}

The animals used in this study were of the Rasa Aragonesa breed and belonged to 6 seropositive flocks. A seronegative accredited Latxa breed flock was used for supply of control animals. The serological test for classification of flocks and animals was based on a recombinant ELISA test (Elitest ${ }^{\circledR}$, Hyphen BioMed, Neuville/Oise, France, formally known as Innotest ${ }^{\circledR}$, Innogenetics, Ghent, Belgium) [38, 44]. A standard agar gel immunodiffusion test (AGID) for MVV (CVL, Weybridge, United Kingdom) was also applied [46]. Seroprevalence to MVV among the seropositive flocks used ranged from 5 to $50 \%$ and all these seropositive flocks had sheep with MVVinduced indurative mastitis after parturition and sheep with interstitial pneumonia caused by MVV. Seventeen adult sheep were selected from the seropositive flocks on the basis of history or the presence of clinical indurative mastitis after parturition and three control animals were selected from the seronegative flock. Only animals free of bacterial mastitis were used, the absence of bacteria being verified by culturing samples of homogenized mammary parenchyma in tryptone-soy-broth and PPLO broth. The serological status of the seronegative flock was determined using the same tests and the results were negative for more than 15 years. 
Table I. Study on mammary glands of sheep from maedi-visna virus (MVV) seropositive flocks (groups A, ELISA positive; and B, ELISA negative) and an MVV-free flock (group C). Serological status: determined by ELISA and AGID tests. Micro lesions: MVV-associated microscopical lesions in the mammary gland. CPE and MVV proteins: detection of cytopathic effect (CPE) and MVV proteins in cultured epithelial cells from explants and in co-cultured choroid plexus cells. MVV protein in tissue: immunocytochemistry for MVV proteins in tissue sections. ISH: presence of proviral DNA by in situ hybridization in tissue sections. TEM: presence of lentiviral-like particles by electronic transmission microscopy studies.

\begin{tabular}{lcccccccc}
\hline Group & Sheep no. & ELISA & AGID & $\begin{array}{c}\text { Micro } \\
\text { lesions }\end{array}$ & $\begin{array}{c}\text { CPE/MVV } \\
\text { proteins }\end{array}$ & $\begin{array}{c}\text { MVV } \\
\text { protein/tissue }\end{array}$ & ISH & TEM \\
\hline A & 1 & + & + & ++ & + & + & NS\# & NS \\
A & $2,3,4$ & + & + & ++ & + & + & + & NS \\
A & $5,6,10$ & + & + & ++ & + & + & + & - \\
A & $7,8,9,11,12$ & + & + & ++ & + & + & + & + \\
A & 13 & + & - & + & + & + & + & NS \\
A & 14 & + & - & + & + & + & + & NS \\
A & 15 & + & $\ldots *$ & ++ & + & + & NS \\
B & 16 & - & - & - & + & + & NS \\
B & 17 & - & $\ldots$ & + & + & + & NS & NS \\
C & $18,19,20$ & - & - & - & - & - & - \\
\hline
\end{tabular}

...*: Inconclusive serum by Agar Gel Immunodiffusion test (AGID). NS\#: specimen not studied.

The animals were distributed, on the basis of the ELISA results, into three groups (Tab. I): (A) seropositive, sheep Nos. 115; (B) seronegative, sheep Nos. 16-17; (C) control animals, sheep Nos. 18-20. The animals were killed by intravenous injection of barbiturate and exsanguinated. Postmortem examination was carried out and samples were collected for further analysis.

\subsection{Histopathology}

A macroscopic study was performed in all animals, with samples from the mammary gland, lung and brain being processed for routine histopathology. Microscopically, lesions in the mammary gland were classified as negative (-) when having a normal pattern, moderate (+) when showing a remarkable number of lymphocytes within the parenchyma, and severe (++) when evidencing the characteristic MVVinduced pathology in the gland (diffuse accumulation of mononuclear cells spe- cially lymphocytes in acini, as well as fibrosis and hyperplasia of lymphatic tissue, with follicle formation close to the lactiferous ducts and also within the alveolar parenchyma [45]).

\subsection{Cultures of ovine mammary epithelial cells}

The mammary gland was sectioned to expose the teat sinus and the glandular cistern. Cultures were carried out in the 20 animals under study as previously described $[5,13]$ and were examined daily for the development of a cytopathic effect (CPE) over a one month period. Detection of CPE was confirmed by Giemsa staining and viral proteins were detected by immunocytochemistry (ICC) using anti-p25 antibody (supplied by G.D. Harkiss, University of Edinburgh, United Kingdom).

Cultures of OMEC from sheep negative to MVV by AGID, ELISA, western blotting 
(strips kindly supplied by Dr G. Harkiss) and histopathology/ ICC were also used to evidence the presence of MVV in vitro. Pure MVV-free OMEC were obtained from the three control animals as previously described $[5,13]$. These cultures were $100 \%$ positive for cytokeratin by ICC, negative to CPE after at least 3 weeks and negative to RTPCR for MVV, using primers for pol and gag regions of the EV1 strain of MVV and sheep Na, K-ATPase primers as internal control for RT-PCR amplification [47]. Confluent monolayers of these OMEC were infected with EV1 strain at $10^{5}$ multiplicity of infection (MOI). Appearance of CPE was studied and RT-PCR was carried out in these infected cultures when CPE was detectable. Finally, the supernatant from these cultures was added to MVV-free ovine foetal choroid plexus cells (SCPC) in culture to allow viral replication in these permissive cells.

\subsection{Productive MVV infection in epithelial cells from mammary gland explants}

Virus specific proteins and induced CPE were examined in the OMEC cultures derived from the 20 sheep. In order to check productive MVV infection, SCPC from MVVfree foetuses were co-cultured with the cultures of OMEC from all sheep. The cultures were examined weekly for the appearance of syncitia and CPE. Cytocentrifuge smears were prepared to detect the presence of viral proteins by ICC (see Sect. 2.5).

\subsection{Immunocytochemistry and immunohistochemistry (IHC)}

Small pieces of mammary gland parenchyma were snap-frozen and stored at $-70^{\circ} \mathrm{C}$. In order to test different antibodies, $5 \mu \mathrm{m}$ sequential sections were obtained with a cryostat. After being air-dried for at least $2 \mathrm{~h}$ at room temperature (RT), immunocyto/histochemical techniques [23] were used in two different kinds of samples: frozen tissue sections and cytocentrifuge preparations obtained from OMEC cultures from all sheep. Also cytocentrifuge preparations obtained from SCPC cultures from the productive MVV infection studies were included for immunocytochemical detection. The monoclonal antibodies $(\mathrm{mAb})$ used were against MVV proteins (MVVp15, $\mathrm{mAb} 415$, supplied by $\mathrm{Dr} \mathrm{D}$. Houwers, University of Utrecht, The Netherlands; MVVp25 supplied by G.D. Harkiss, and MVVp27, supplied by Dr J. De Martini, Colorado State University, USA) and cytokeratin (mAb AE1-AE3, Boehringer Mannheim, Mannheim, Germany). The specificity of staining was demonstrated by including negative controls (bronchoalveolar lavage smears and tissue sections from MVV negative animals) and a known positive control (MVV-experimentally infected SCPC). Another control consisted on the omission or substitution of primary $\mathrm{mAb}$.

\subsection{In situ hybridization (ISH)}

Digoxigenin-labeled probes were used for in situ hybridization, the fragment of DNA being a 512 nt product of the gag region [4] of the CAEV genome. This fragment had been shown to detect a number of strains of ovine lentiviruses and was produced by Nested-PCR. Labeling with digoxigenin was performed according to the manufacturer's instructions (DIG-High Prime; Boehringer Mannheim), the stain used being Pellet Paint ${ }^{\mathrm{TM}}$ Co-Precipitant (Novagen, Madison, WI, USA).

Tissue sections embedded in paraffin were used for ISH studies. Samples from the mammary gland parenchyma from sheep Nos. 2-12, 14, 15 (group A) and 18-20 (group C) were fixed in $10 \%$ buffered formalin for 24-72 $\mathrm{h}$ and embedded in paraffin. Cryostat sections were transferred onto coated charged glass slides (Hirschmann Laboratories, Eberstadt, Germany) and dried at $37^{\circ} \mathrm{C}$. Paraffin was removed with xylene, the sections were cleaned with two $10 \mathrm{~min}$ washes of $100 \%$ alcohol and dried. The sections were permeabilized with pepsin for $15 \mathrm{~min}$ at $40^{\circ} \mathrm{C}$ in a humidified chamber. A wash in distilled water followed. The 
sections were dehydrated through a graded alcohol series and air-dried. The probe was diluted into Probe Diluent (Biomeda Corporation, Suite F Fostercity, CA, USA), at concentrations ranging from 1 to $5 \%$, using $100 \mu \mathrm{L}$ for sections. The probe-containing fluid was evenly spread over each sample by placing a large coverslip on top. The sections were heated in a thermal block at $90{ }^{\circ} \mathrm{C}$ for $3 \mathrm{~min}$. Hybridization was performed overnight at $40{ }^{\circ} \mathrm{C}$ in a humidified chamber. Coverslips were removed and the slides were washed twice in $0.5 \times$ Probe Wash (Biomeda Corporation) at $22-24{ }^{\circ} \mathrm{C}$. An additional wash was performed with the same buffer at $65^{\circ} \mathrm{C}$ for $2 \mathrm{~h}$. The slides were rinsed in Tris-buffered saline (TBS) for $10 \mathrm{~min}$ at $22-24{ }^{\circ} \mathrm{C}$ and incubated with alkaline phosphatase-conjugated anti-digoxigenin Fab fragment solution (1:200, Boehringer Mannheim), for $1 \mathrm{~h}$ in a humidified chamber at $22-24{ }^{\circ} \mathrm{C}$, and finally washed in TBS three times for $10 \mathrm{~min}$. The slides were incubated for $30-60 \mathrm{~min}$ in alkaline phosphatase substrate buffer (NBT/ BCIP, Pierce Biotechnology, Rockford, IL, USA) in a humidified chamber at $22-24{ }^{\circ} \mathrm{C}$. They were then rinsed twice with distilled water and counterstained with Nuclear Fast Red (Sigma Aldrich, St. Louis, MO, USA). The reaction was stopped with tap water and preparations were rinsed with distilled water, covered with Crystal Mount (Biomeda Corporation) and dried at $60^{\circ} \mathrm{C}$. Once Crystal Mount was dry, permanent mounting was achieved by using DPX mounting medium (Sigma Aldrich). Cytospins of MVV EV1-infected choroid plexus cells and MVV positive tissues were used as positive controls. A non-related plasmid DNA was used as a negative control in each hybridization reaction.

\subsection{Ultrastructural studies}

Samples of mammary gland parenchyma and cistern for transmission electron microscopy (TEM) examination were obtained from sheep Nos. 5-12 and 18-20 and were fixed in Karnowsky fixative. The samples were then sectioned in cubes of approximately $1 \mathrm{~mm}^{3}$, washed overnight in $0.1 \mathrm{M}$ phosphate buffer, post-fixed in $1 \%$ osmium tetroxide and dehydrated in an ascending grade of ethanol and embedded in epoxy resin (Epon 812, Fluka, Buchs SG, Switzerland). Ultrathin sections $(50 \mathrm{~nm})$ were stained with uranyl acetate and lead citrate and observed in a Philips CM-10 transmission electron microscope.

\section{RESULTS}

\subsection{Serological observations}

ELISA and AGID results are shown in Table I. In Group A, twelve sheep were positive in both tests, and three were positive by ELISA, but negative or inconclusive by AGID. In Group B, one animal was negative by both tests and the other was negative by ELISA and inconclusive by AGID. The animals of the control group were negative by both tests.

\subsection{Clinical signs and pathological findings}

All the animals from the infected flocks presented an indurative mastitis with a diffuse, bilateral hardening of the gland and with a firm and uniform section. Sheep were slaughtered within two months after parturition. All animals in group A showed microscopical lesions, although in two of the animals the lesions were only moderate. In Group B, sheep No. 17 also showed moderate lesions and sheep No. 16 was free of MVV-associated lesions but presented a marked and diffuse fibrosis of the gland. Remarkably, only one animal (No. 10) had MVV-related lesions in the lung. Control animals were free of lesions.

\subsection{Productive MVV infection in epithelial cells from mammary tissue explants}

Productive MVV infection in OMEC from mammary tissue explants (defined as 


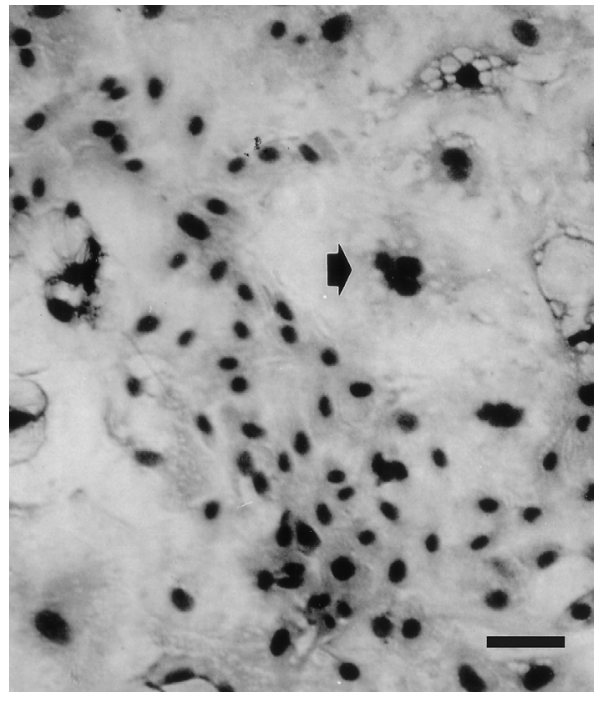

Figure 1. Ovine mammary gland epithelial cell (OMEC) culture from maedi-visna naturally infected sheep, showing the presence of cytopathic effect and syncitium formation (arrow). Giemsa staining. Bar: $32 \mu \mathrm{m}$.

the presence of CPE, detection of MVVassociated proteins in cell cytoplasm, and infectivity by co-culture) was detected in the sheep of group A (with the exception of sheep No. 16) and in one sheep (No. 17) of group $\mathrm{B}$ but in none of the group $\mathrm{C}$ animals (Tab. I). These OMEC disclosed CPE after four weeks in culture (Fig. 1), with the MVV antigens being detected in these cells by ICC. Productive infection was finally confirmed by the appearance of CPE and the presence of MVV proteins in SCPC cocultured with these OMEC. Cytokeratinstained epithelial cells showed a diffuse, intense grey staining in the cytoplasm. The totality of the cells in OMEC preparations and none of the choroid plexus cells used as controls were stained by cytokeratin mAb. OMEC controls labeled with unrelated $\mathrm{mAb}$ were not stained. OMEC from the control group animals were free of MVV.

\subsection{Experimental infection of MVV-free mammary epithelial cells cultures in vitro}

OMEC cultures free of MVV (according to PCR and MVV protein staining) were experimentally infected in vitro with the strain EV1, developing CPE after five days. The RT-PCR amplicons obtained then with these cells had the expected size (142 nt for gag and $280 \mathrm{nt}$ for pol) and were observed only in cultures showing CPE, confirming that OMEC had been successfully infected in vitro. ATPase amplicons demonstrated a correct RT-PCR amplification in all the samples. When supernatants of these infected OMEC cultures were added to cultured MVV-free fibroblasts, these cells developed CPE after four days, also being MVV positive by RT-PCR. These results further confirmed that productive infection of OMEC is achieved with experimentally infected OMEC.

\subsection{Viral detection in tissue sections}

The presence of the virus was observed by IHC and ISH within the mammary gland stroma mainly in cells morphologically compatible with macrophages that were located around the acini and lymphoid follicles, as well as in the interstitium. However, viral presence was also found in individual acinar cells morphologically compatible with epithelial cells by IHC and ISH, the strongest signal by IHC being located at the apical cell border (Figs. 2 and 3). Sections treated with unrelated $\mathrm{mAb}$ showed no staining by IHC and no reaction by ISH. Sheep Nos. 16 and 18-20 showed no positive reaction to viral antigens (Tab. I). Lentivirus-like budding particles were observed by TEM at the apical cell border of a few milk-secreting OMEC in sheep Nos. 7-9, 11 and 12 , showing the characteristic thickening of the cellular membrane (Figs. 4 and 5). Particles were sometimes observed free in the acinar lumen. No particles were observed in the preparations from sheep Nos. 5-6, 10 and 18-20 (Tab. I). 


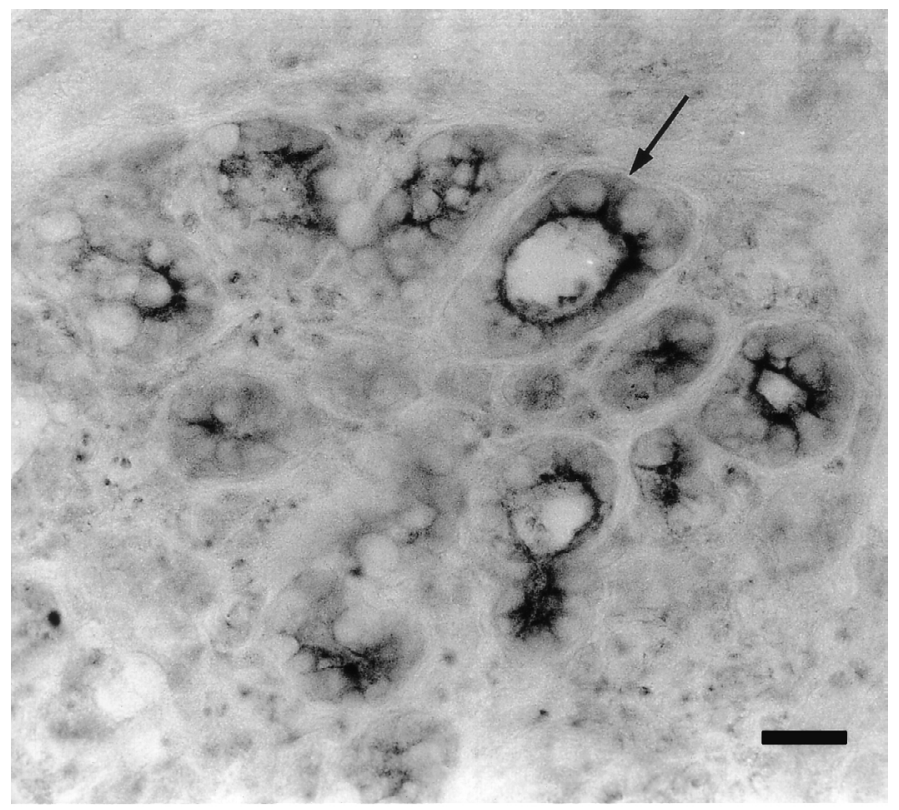

Figure 2. Tissue sections from maedi-visna naturally infected sheep showing positive signals to MVV in the alveolar lining cells by single immunocytochemistry (p25 antibody). Bar: $60 \mu \mathrm{m}$.

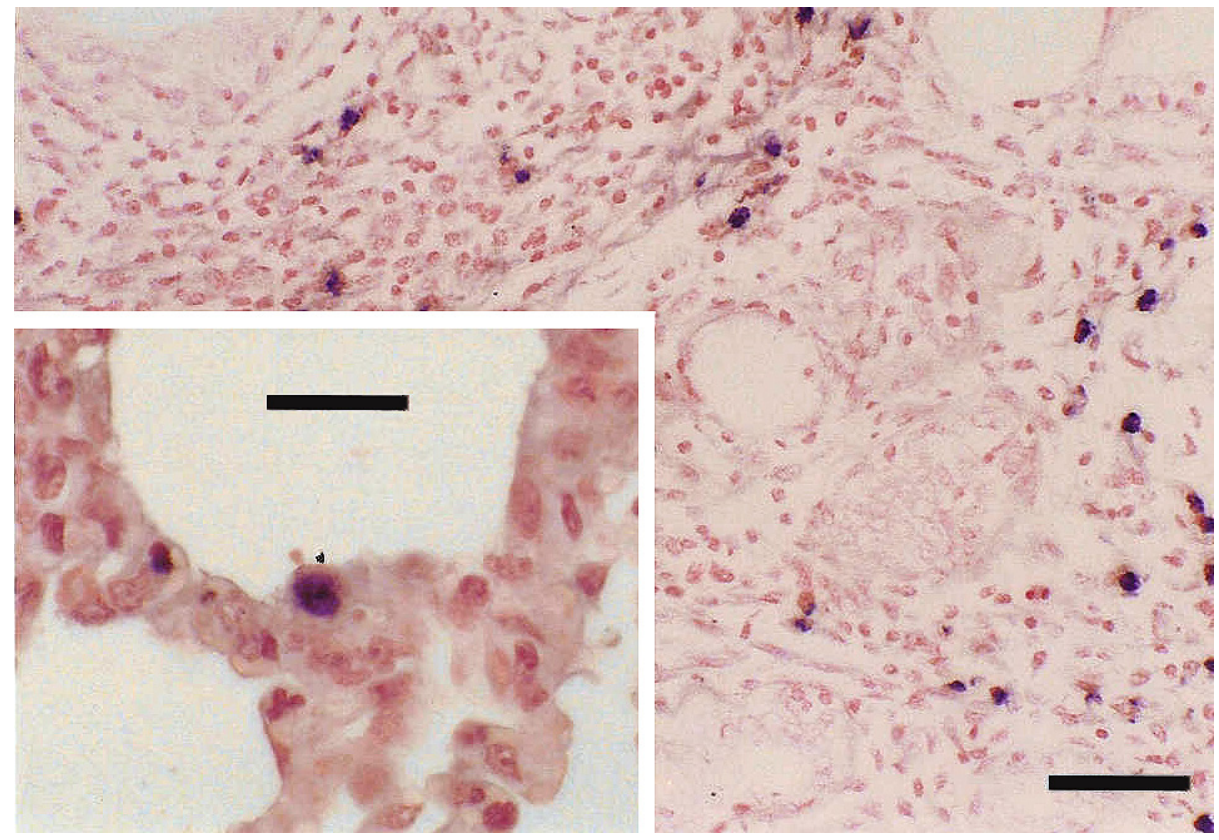

Figure 3. Tissue sections from maedi-visna naturally infected sheep studied by in situ hybridization. Positive cells are located within the inflammatory reaction. Bar: $40 \mu \mathrm{m}$. Insert: A single positive cell morphologically compatible with an OMEC. Bar: $20 \mu \mathrm{m}$. 


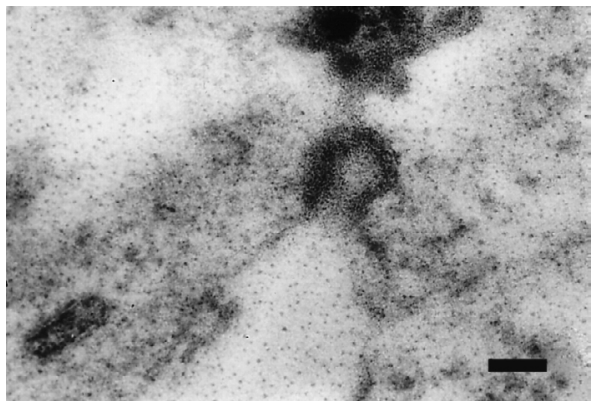

Figure 4. Mammary gland tissue section of maedi-visna naturally infected sheep. A lentivirus-like particle is observed at the apical cell border by transmission electron microscopy. Bar: $125 \mathrm{~nm}$.

\section{DISCUSSION}

Analysis of MVV-affected ovine mammary gland revealed in this study that OMEC undergo infection. Detection of viral proteins and viral nucleic acids in the OMEC indicates that cells undergoing MVV infection in the udder are not only macrophages but also OMEC. Additionally, the presence of budding particles at the OMEC cell membrane level strongly suggests that OMEC cells give rise to infective virus and, therefore, are productively infected; a fact that is further supported by the infection of susceptible cells in co-cultures with infected OMEC.

Previous in vitro studies demonstrated that lentivirus-free goat and sheep mammary epithelial cells can be experimentally infected with CAEV [20]. We further demonstrate that MVV can experimentally infect OMEC in vitro. These cells not only presented a CPE associated with the presence of MVV proteins, but also the corresponding culture supernatants were able to productively infect choroid plexus cells. A similar type of CPE have been reported to happen after 3 weeks of culture in goat mammary epithelial cells (GMEC) infected with lentivirus [20]. In addition, the co-culture of SCPC with the OMEC explants from

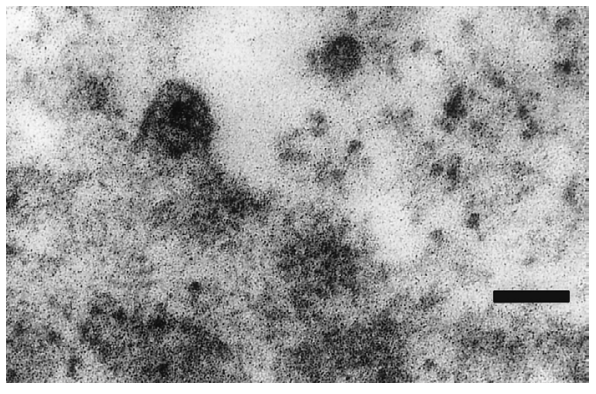

Figure 5. Characteristic budding particle with thickening of the cell membrane, shown by transmission electron microscopy. Bar: $100 \mathrm{~nm}$.

MVV naturally-infected sheep, show that these OMEC explants were also able to undergo productive infection during in vitro culture. The role of accessory cells as a source of MVV in cultures is unlikely to have happened because macrophages were removed by selective trypsinisation during the first week of culture and the presence of fibroblasts would have been detected by features such as earlier and more lytic CPE [20].

These observations underline that apparently no accessory cells are needed for MVV presentation and replication in OMEC. MVV can replicate in vitro in a wide variety of ovine cells [30], because the restriction that the virus presents under natural conditions is no longer maintained in vitro [29]. Similarly, CAEV, the caprine counterpart of MVV, can replicate in a variety of cells in vitro [14, 15, 20, 27, 28, 37] and, significantly, HIV-1 can also productively infect different cell lines in vitro including human OMEC [43].

IHC, ISH and TEM observations have demonstrated the in vivo presence of MVV in the acinar epithelia, indicating that OMEC are permissive for MVV infection in vivo and strongly suggesting that these cells may give rise to infective particles in natural conditions. In vivo MVV infection of the mammary gland is likely initiated by infected blood monocytes, which differentiate into macrophages in the mammary 
tissue $[8,18]$. Once differentiated, a direct macrophage-OMEC contact can be a mechanism of OMEC or macrophage infection within the mammary gland. It has been suggested from in vitro studies on CAEV infectivity that OMEC can be the targets for CAEV in the sheep mammary gland [20]. This is compatible with the proposal from in vitro studies that the myoepithelial cell may act as a reservoir cell and that, after infection, the mature luminal cell (OMEC) acquires the capacity to bind leukocytes and facilitates cellular interactions [24] and viral transmission. These observations are in agreement with our finding that not only macrophages but also OMEC may have a role in replication and as a reservoir of the virus in this organ and in MVV pathogenesis. A variety of epithelial cells are in vivo targets for lentiviruses and other retroviruses. MVV proviral DNA has been detected in MVV experimentally-infected bronchial epithelial cells [42], and CAEV proviral DNA has been observed in epithelial cells of the intestinal crypts [48]. Similarly, bovine leukaemia virus can replicate in OMEC in natural infection [2] and feline immunodeficiency virus (FIV) replicates in the salivary gland epithelium [33].

Virus-like particles reaching the acinar lumen, also observed by TEM in a previous work [17], are most likely present in milk, where MVV has been detected mainly in infected macrophages [31] that have traversed the epithelial barrier by a wellknown mechanism [7, 8]. Furthermore, milk can also have OMEC [19], and some of these cells can be infected in MVV infected animals with clinical mastitis, confirming that milk may be a very important route of infection to the newborn lamb [8]. These findings are consistent with the widely accepted phenomenon of newborn lamb MVV infection through maternal milk at early stages of life [7,9], and with previous observations that MVV can be isolated from mammary tissue [18] and milk [19]. Remarkably, CAEV appears to spread mainly through colostrum and milk $[1,9]$ and the feline immunodeficiency virus
(FIV) can also be transmitted via milk [40]. Moreover, MVV could enter the OMEC but infectious virus could be produced after OMEC activation. OMEC may provide an in vivo reservoir for the persistence of proviral MVV with the production and release of infectious viruses after cell reactivation by host factors, for example hormones [20]. It is important to underline that all positive animals studied in our work were in the post-partum period, and this could be linked to the detection and production of MVV in OMEC.

Milk can be an important fluid for MVV infection diagnosis. However, some of the MVV clinical mastitis animals do not produce milk, and serological methods may then be of higher diagnostic value. The association found in this study between clinical mastitis, seropositivity to MVV by ELISA and viral detection in the mammary gland was high, with one exception. Among the serologic tests used in this study to detect MVV antibodies, the increased sensitivity observed in the ELISA with respect to AGID was expected according to previous studies [38, 44] and confirmed by the presence of viral genome and proteins in histopathological observations.

In conclusion, the present study broadens the cellular spectrum of MVV distribution beyond the macrophage-monocyte lineage. The role of the OMEC as a reservoir of MVV in vivo provides new insight on MVV pathogenesis in the mammary gland and brings up new issues in the study of MVV replication and transmission to healthy cells, different tissues and uninfected animals. Additionally, our results support the role of milk as an important route of infection to the newborn lamb.

\section{ACKNOWLEDGEMENTS}

Supported by grants from MCYT ref. AGL2003-08977-C03-02, AGL2003-08977C03-01 and from the Research Consolidated Groups from the Aragon Government. We sincerely thank Dr G. Harkiss for Western Blotting, Dr J.C. De Martini, Dr G.D. Harkiss and 
Dr Houwers for the generous gift of monoclonal antibodies and Santiago Becerra for technical assistance.

\section{REFERENCES}

[1] Adams D.S., Klevjer-Anderson P., Carlson J.L., McGuire T.C., Gorham J.R., Transmission and control of caprine arthritis-encephalitis virus, Am. J. Vet. Res. 44 (1983) 16701675 .

[2] Buehring G.C., Kramme P.M., Schultz R.D., Evidence for bovine leukemia virus in mammary epithelial cells of infected cows, Lab. Invest. 71 (1994) 359-365.

[3] Carrozza M.L., Mazzei M., Bandecchi P., Arispici M., Tolari F., In situ PCR-associated immunohistochemistry identifies cell types harbouring the Maedi-Visna virus genome in tissue sections of sheep infected naturally, J. Virol. Methods 107 (2003) 121-127.

[4] Chebloune Y., Sheffer D., Karr B.M., Stephens E., Narayan O., Restrictive type of replication of ovine/caprine lentiviruses in ovine fibroblast cell cultures, Virology 222 (1996) 21-30.

[5] Cifrián E., Guidry A.J., O’Brien C.N., Nickerson S.C., Marquardt W.W., Adherence of Staphylococcus aureus to cultured bovine mammary epithelial cells, J. Dairy Sci. 77 (1994) 970-983.

[6] Craig L.E., Nealen M.L., Strandberg J.D., Zink M.C., Differential replication of ovine lentivirus in endothelial cells cultured from different tissues, Virology 238 (1997) 316326.

[7] Cutlip R.C., Lehmkuhl H.D., Schmerr M.J., Brodgen K.A., Ovine progressive pneumonia (maedi-visna) in sheep, Vet. Microbiol. 17 (1988) 237-250.

[8] De La Concha-Bermejillo A., Maedi-visna and ovine progressive pneumonia, Vet. Clin. North Am. Food Anim. Pract. 13 (1997) 13-33.

[9] Ellis T., Robinson W., Wilcox G., Effect of colostrum deprivation of goat kids on the natural transmission of caprine retrovirus infection, Aust. Vet. J. 60 (1983) 326-329.

[10] Georgsson G., Houwers D.J., Pálsson P.A., Pétursson G., Expression of viral antigens in the central nervous system of visna-infected sheep: an immunohistochemical study on experimental visna induced by virus strains of increased neurovirulence, Acta Neuropathol. 77 (1989) 299-306.

[11] Gorrell M.D., Brandon M.R., Sheffer D., Adams R.J., Narayan O., Ovine lentivirus is macrophagetropic and does not replicate productively in T lymphocytes, J. Virol. 66 (1992) 2679-2688.

[12] Houwers D.J., Pekelder J.J., Akkermans J.W.P.M., Molen E.J.V.D., Schreuder B.E.C., Incidence of indurative lymphocytic mastitis in a flock of sheep infected with maedi-visna virus, Vet. Rec. 122 (1988) 435-437.

[13] Iturralde M., Aguilar B., Baselga R., Amorena B., Adherence of ruminant mastitis Staphylococcus aureus strains to epithelial cells from ovine mammary gland primary cultures and from a rat intestinal cell line, Vet. Microbiol. 38 (1993) 115-127.

[14] Lamara A., Fieni F., Mselli-Laakhaal L., Tainturier D., Chebloune Y., Efficient replication of caprine arthritis-encephalitis virus in goat granulosa cells, Virus Res. 79 (2001) 165-172.

[15] Lamara A., Fieni F., Mselli-Laakhaal L., Chatagnon G., Bruyas J.F., Tainturier D., Battut I., Fornazero C., Chebloune Y., Early embryonic cells from in vivo-produced goat embryos transmit the caprine arthritisencephalitis virus (CAEV), Theriogenology 58 (2002) 1153-1163.

[16] Lamara A., Fieni F., Mselli-Laakhaal L., Tainturier D., Chebloune Y., Epithelial cells from goat oviduct are highly permissive for productive infection with caprine arthritisencephalitis virus (CAEV), Virus Res. 87 (2002) 69-77.

[17] Lee W.C., McConnell I., Blacklaws B.A., Electron microscope studies of the replication of a British isolate of maedi visna virus in macrophages and skin cell lines, Vet. Microbiol. 49 (1996) 93-104.

[18] Lerondelle C., Le Gall C., L'infection de la mamelle par le virus visna maedi, Sci. Vét. Méd. Comp. 93 (1991) 183-188.

[19] Lerondelle C., Ouzrout R., Expression of maedi-visna virus in mammary secretions of a seropositive ewe, Dev. Biol. Stand. 72 (1990) 223-227.

[20] Lerondelle C., Godet M., Mornex J.F., Infection of primary cultures of mammary epithelial cells by small ruminant lentiviruses, Vet. Res. 30 (1999) 467-474. 
[21] Leroux C., Gordier G., Mercier I., Chastang J., Lyon M., Quérat G., Greenland T., Vigne R., Mornex J.F., Ovine aortic smooth muscle cells allow the replication of visna-maedi virus in vitro, Arch. Virol. 140 (1995) 1-11.

[22] Luján L., García Marín J.F., Fernández de Luco D., Vargas A., Badiola J.J., Pathological changes in the lungs and mammary glands of sheep and their relationship with maedi-visna infection, Vet. Rec. 129 (1991) 51-54.

[23] Luján L., Begara I., Collie D.D.S., Watt N.J., Ovine lentivirus (maedi-visna virus) protein expression in sheep alveolar macrophages, Vet. Pathol. 31 (1994) 695-703.

[24] Milhau N., Renson P., Dreesen I., Greenland T., Bellaton C., Guiguen F., Mornex J.F., Le Jan C., Viral expression and leukocyte adhesion after in vitro infection of goat mammary gland cells with caprine arthritis-encephalitis virus, Vet. Immunol. Immunopathol. 103 (2005) 93-99.

[25] Molen E.J.V.D., Houwers D.J., Indurative lymphocitic mastitis in sheep after experimental infection with maedi-visna virus, Vet. Q. 9 (1987) 193-202.

[26] Molen E.J.V.D., Vecht U., Houwers D.J., A chronic indurative mastitis in sheep, associated with maedi/visna virus infection, Vet. Q. 7 (1985) 112-119.

[27] Mselli-Laakhal L., Guiguen F., Fornazero C., Du J., Favier C., Durand J., Grezel D., Balleydier S., Mornex J.F., Chebloune Y., Goat milk epithelial cells are highly permissive to CAEV infection in vitro, Virology 259 (1999) 67-73.

[28] Mselli-Laakhal L., Guiguen F., Fornazero C., Du J., Favier C., Durand J., Grezel D., Balleydier S., Mornex J.F., Chebloune Y., Immortalized goat milk epithelial cell lines replicate CAEV at high level, Vet. Res. 32 (2001) 429-440.

[29] Narayan O., Sheffer D., Clements J.E., Tennekoon G., Restricted replication of lentiviruses, J. Exp. Med. 162 (1985) 1954-1969.

[30] Narayan O., Zink M.C., Gorell M., Crane S., Huso D., Jolly P., Saltarelli M., Adams R.J., Clements J.E., The lentiviruses of sheep and goats, in: Levy J.A. (Ed.), The retroviridae, Plenum Press, New York, Vol. 1, 1992, pp. 229-255.

[31] Ouzrout R., Guiguen F., Lerondelle C., Évolution des sous-populations lymphocytaires dans le lait de brebis au moment de l'excrétion du virus maedi, Ann. Rech. Vet. 22 (1991) 379-386.
[32] Pálsson P.A., Maedi-visna. History and clinical description, in: Pétursson G., Hoff-Jørgensen R. (Eds.), Maedi-visna and related diseases, Kluwer Academic Publishers, Massachusetts, 1990, pp. 2-17.

[33] Park H.S., Kyaw-Tanner M., Thomas J., Rodinson W.F., Feline immunodeficiency virus replicates in salivary gland epithelium during the initial phase of infection, Vet. Microbiol. 46 (1995) 257-267.

[34] Pekelder J.J., Veenik G.J., Akkermans J.P.W.M., Eldik P., Elving L., Houwers D.J., Ovine lentivirus induced indurative lymphocytic mastitis and its effect on the growth of lambs, Vet. Rec. 134 (1994) 348-350.

[35] Peluso R., Haase A., Stowring L., Edwars M., Ventura P., A trojan horse mechanism for the spread of visna virus in monocytes, Virology 147 (1985) 231-236.

[36] Peterhans E., Greenland T., Badiola J., Harkiss G., Bertoni G., Amorena B., Eliaszewicz M., Juste R.A., Krassnig R., Lafont J.P., Lenihan P., Petursson G., Pritchard G., Thorley J., Vitu C., Mornex J.F., Pepin M., Routes of transmission and consequences of small ruminant lentiviruses (SRLVs) infection and eradication schemes, Vet. Res. 35 (2004) 257-274.

[37] Robinson W.F., Ellis T.M., Caprine arthritisencephalitis virus infection: from recognition to eradication, Aust. Vet. J. 63 (1986) 237241.

[38] Saman E., Van Eynde G., Lujan L., Extramiana B., Harkiss G., Tolari F., Gonzalez L., Amorena B., Watt N., Badiola J.J., A new sensitive serological assay for detection of lentivirus infections in small ruminants, Clin. Diagn. Lab. Immunol. 6 (1999) 734-740.

[39] Scott G.B., Buck B.E., Leterman J.G., Bloom F.L., Parks W.P., Acquired immunodeficiency syndrome in infants, N. Engl. J. Med. 310 (1984) 76-81.

[40] Sellon R.K., Jordan H.L., Kennedy-Stoskopf S., Tompkins M.B., Tompkins W.A.F., Feline immunodeficiency virus can be experimentally transmitted via milk during acute maternal infection, J. Virol. 68 (1994) 3380-3385.

[41] Sigurdsson B., Maedi, a slow progressive pneumonia of sheep: an epizoological and a pathological study, Br. Vet. J. 110 (1954) 225-270.

[42] Staskus K.A., Couch L., Bitterman P., Retzel E.F., Zupancic M., List J., Haase A.T., In situ amplification of visna virus DNA in tissue 
sections reveals a reservoir of latently infected cells, Microb. Pathog. 11 (1991) 67-76.

[43] Toniolo A., Serra C., Giulio P.C., Basolo F., Falcone V., Dolei A., Productive HIV-1 infection of normal human mammary epithelial cells, AIDS 9 (1995) 859-866.

[44] Varea R., Monleon E., Pacheco C., Lujan L., Bolea R., Vargas M.A., Van Eynde G., Saman E., Dickson L., Harkiss G., Amorena B., Badiola J.J., Early detection of maedi-visna (ovine progressive pneumonia) virus seroconversion in field sheep samples, J. Vet. Diagn. Invest. 4 (2001) 301-307.

[45] Watt N.J., King T.J., Collie D., McIntyre N., Sargan D., McConnell I., Clinicopathological investigation of primary, uncomplicated maedivisna virus infection, Vet. Rec. 131(1994) 455-461.

[46] Winward L.D., Leendertsen L., Shen D.T., Microimmunodiffusion test for diagnosis of ovine progressive pneumonia, Am. J. Vet. Res. 40 (1979) 564-566.

[47] Woodall C.J., Mylne J., McKelvie W.A.C., Watt N.J., A technique for the sequential isolation of RNA and DNA from embryos developed for screening for viruses, J. Virol. Methods 46 (1994) 263-274.

[48] Zink M.C., Yager J.A., Myers J.D, Pathogenesis of caprine arthritis encephalitis virus, Am. J. Pathol. 136 (1990) 843-854. 